\title{
The Bcr-Abl kinase inhibitor INNO-406 induces autophagy and different modes of cell death execution in Bcr-Abl-positive leukemias
}

\author{
Y Kamitsuji ${ }^{1,2,3,4}$, J Kuroda ${ }^{4}$, S Kimura ${ }^{2}$, S Toyokuni ${ }^{5}$, K Watanabe $^{1}$, E Ashihara ${ }^{2}$, H Tanaka ${ }^{6}$, Y Yui ${ }^{1}$, M Watanabe ${ }^{1}$, H Matsubara ${ }^{1}$, \\ Y Mizushima ${ }^{1}$, Y Hiraumi ${ }^{1}$, E Kawata ${ }^{2,3}$, T Yoshikawa $^{3}$, T Maekawa ${ }^{2}$, T Nakahata ${ }^{1}$ and S Adachi ${ }^{\star 1}$
}

Bcr-Abl tyrosine kinase (TK) inhibitors are promising therapeutic agents for Bcr-Abl-positive $\left(\mathrm{Bcr}-\mathrm{Abl}{ }^{+}\right)$leukemias. Although they are known to promote caspase-mediated apoptosis, it remains unclear whether caspase-independent cell death-inducing mechanisms are also triggered. Here we demonstrated that INNO-406, a second-generation Bcr-Abl TK inhibitor, induces programmed cell death (PCD) in chronic myelogenous leukemia (CML) cell lines through both caspase-mediated and caspaseindependent pathways. The latter pathways include caspase-independent apoptosis (CIA) and necrosis-like cell death (CIND), and the cell lines varied regarding which mechanism was elicited upon INNO-406 treatment. We also observed that the propensity toward CIA or CIND in cells was strongly associated with cellular dependency on apoptosome-mediated caspase activity. Cells that undergo CIND have a high apoptosome activity potential whereas cells that undergo CIA tend to have a lower potential. Moreover, we found that INNO-406 promotes autophagy. When autophagy was inhibited with chloroquine or gene knockdown of beclin1 by shRNA, INNO-406-induced cell death was enhanced, which indicates that the autophagic response of the tumor cells is protective. These findings suggest new insights into the biology and therapy of $\mathrm{Bcr}^{-\mathrm{Abl}}{ }^{+}$leukemias.

Cell Death and Differentiation (2008) 15, 1712-1722; doi:10.1038/cdd.2008.107; published online 11 July 2008

Chronic myelogenous leukemia $(\mathrm{CML})$ is caused by the specific chromosomal aberration $\mathrm{t}(9 ; 22)$ that is known as the Philadelphia (Ph)-chromosome. This results in Bcr-Ablpositive $\left(\mathrm{Bcr}-\mathrm{Abl}^{+}\right.$) cells that bear the constitutively active Bcr-Abl tyrosine kinase (TK), which is the product of the Ph-chromosome and which drives leukemogenesis. ${ }^{1,2}$ TK inhibitors that bind to the Abl TK active site in Bcr-Abl and thereby shut down Bcr-Abl signaling have been developed. These drugs have proved to be highly promising in $\mathrm{CML}$ therapy as they induce Bcr-Abl ${ }^{+}$leukemic cell death, principally through the mitochondria-mediated intrinsic apoptosis pathway. ${ }^{3-5}$ One such TK inhibitor is imatinib mesylate (Gleevec $^{\mathrm{TM}}$; Glivec ${ }^{\mathrm{TM}}$; formerly STI571), which has been shown to effectively treat $\mathrm{Ph}^{+}$leukemias, including $\mathrm{CML}$ and $\mathrm{Ph}^{+}$ acute lymphoblastic leukemia (ALL) ${ }^{6,7}$ Indeed, the development of imatinib dramatically altered the first-line therapy for CML. However, a small percentage of $\mathrm{CML}$ and $\mathrm{Ph}^{+} \mathrm{ALL}$ patients, particularly those with advanced-phase disease, are refractory to imatinib therapy or suffer relapses. ${ }^{7,8}$ To over- come resistance to imatinib, we recently developed INNO-406 (formerly NS-187), which is a specific dual Bcr-Abl/Lyn inhibitor that kills $\mathrm{Bcr}_{-\mathrm{Abl}}{ }^{+}$cells $25-55$ times more effectively than imatinib in vitro and at least 10 times more effectively in vivo. $^{9}$

A decade of intensive research has revealed several mechanisms that induce programmed cell death (PCD). These mechanisms can be caspase-dependent or caspaseindependent. The latter category include caspase-independent apoptosis ( $\mathrm{CIA}$ ), which employs mitochondrial molecules other than cytochrome (cyt) $c$, as well as other modes of cell death such as autophagic cell death, mitotic catastrophe, or caspase-independent necrosis-like cell death (CIND). ${ }^{10-13}$ We have reported that imatinib induces CIND in $\mathrm{Bcr}-\mathrm{Abl}^{+}$ leukemias. ${ }^{14}$ We and others have also elucidated how Bcr-Abl TK inhibitors initiate apoptosis in $\mathrm{Bcr}^{-\mathrm{Abl}^{+}}$leukemias (by engaging pro-apoptotic BH3-only proteins such as Bim). ${ }^{5}$ However, the events that take place after mitochondrial outer membrane permeabilization (MOMP) are yet to be fully

\footnotetext{
${ }^{1}$ Department of Pediatrics, Graduate School of Medicine, Kyoto University, Kyoto, Japan; ${ }^{2}$ Department of Transfusion Medicine and Cell Therapy, Kyoto University Hospital, Kyoto, Japan; ${ }^{3}$ Department of Molecular Medicine, Graduate School of Medical Science, Kyoto Prefectural University of Medicine, Kyoto, Japan; ${ }^{4}$ Division of Hematology and Oncology, Department of Medicine, Kyoto Prefectural University of Medicine, Kyoto, Japan; ${ }^{5}$ Department of Pathology, Graduate School of Medicine, Kyoto University, Kyoto, Japan and ${ }^{6}$ Department of Hematology and Oncology, Research Institute for Radiation Biology and Medicine, Hiroshima University, Hiroshima, Japan

${ }^{*}$ Corresponding author: S Adachi, Department of Pediatrics, Graduate School of Medicine, Kyoto University, 54 Shogoin Kawahara-cho Sakyo-ku Kyoto, Kyoto 606-8507, Japan.

Tel: + 81757513301 ; Fax: + 81757522361 ; E-mail: adachiso@kuhp.kyoto-u.ac.jp

Keywords: apoptosis; autophagy; Bcr-Abl; caspase; INNO-406

Abbreviations: AIF, apoptosis-inducing factor; ALL, acute lymphoblastic leukemia; Apaf-1, apoptotic protease-activating factor-1; BC, blast crisis; BM, bone marrow; $\mathrm{CIA}$, caspase-independent apoptosis; CIND, caspase-independent necrosis-like cell death; CML, chronic myelogenous leukemia; $C Q$, chloroquine; cyt, cytochrome; DiOC6(3), 3,3'-dihexyloxacarbocyanine iodide; EM, electron microscopy; HE, hematoxilin-eosin; IAP, inhibitors of apoptosis protein; IF, immunofluorescent; IgG, immunoglobulin G; IHC, immunohistochemical; LC3, light chain 3; LM, light microscopy; MOMP, mitochondrial outer membrane permeabilization; PB, peripheral blood; PCD, programmed cell death; Ph, Philadelphia; PI, propidium iodide; PI3K, phosphoinositide-3-kinase; STAT5, signal transducer and activator of transcription; TK, tyrosine kinase; WB, western blotting; XIAP, X-linked inhibitor of apoptosis protein; zVAD, ZVAD-fmk; 3-MA, 3-methyladenine; sh, short hairpin Received 21.1.08; revised 26.5.08; accepted 11.6.08; Edited by D Klionsky; published online 11.7.08
} 
defined, although caspase activity has been suggested to be essential for this process. ${ }^{15,16}$

Here we investigated how $\mathrm{Bcr}-\mathrm{Abl}^{+}$leukemic cell death is executed after MOMP when Bcr-Abl signaling is blocked by INNO-406 treatment. As observed previously, ${ }^{11,17,18}$ we found that INNO-406 induces caspase-dependent apoptosis in $\mathrm{Bcr}-\mathrm{Abl}^{+}$leukemic cell lines and patient-derived Bcr-Abl ${ }^{+}$ leukemic cells. However, we also found that under caspaseinactive conditions in vitro, INNO-406 triggers CIA or delayed CIND, depending on the cell clone. Significantly, CIA was favored as the PCD mechanism when the potential of the cyt $c$-induced apoptosome to activate caspase in the cell was low, whereas CIND was triggered in cells that had a high apoptosome potential. These observations suggest that drugs such as INNO-406 that can activate caspase-independent PCD mechanisms may be highly useful for the treatment of cancers that show impaired caspase-dependent apoptosis.

Treatment with anticancer agents, including TK inhibitors, has been shown to induce cellular autophagy in Bcr-Abl ${ }^{+}$ leukemias. ${ }^{19}$ It has been speculated that this autophagy may either be a type-2 PCD process (autophagic cell death) or a mechanism that protects the cell in energy-insufficient conditions. $^{20-23}$ In our study here, we also observed autophagy in the INNO-406-treated leukemic cells in caspase-inactive conditions, especially those undergoing CIND. However, experiments blocking autophagy by employing chloroquine (CQ), 3-methyladenine (3-MA) and short hairpin (sh) RNA knockdown of beclin1 revealed that the autophagy induced by INNO-406 is likely to be a cell-protective response. That INNO-406 therapy induces autophagy provides new insights into the biology and treatment of $\mathrm{Bcr}-\mathrm{Abl}{ }^{+}$leukemias.

\section{Results}

INNO-406 induces $\mathrm{Bcr}^{-A b I^{+}}$leukemia cell lines to undergo both caspase-mediated and caspaseindependent cell death. By blocking the phosphorylation of Bcr-Abl, INNO-406 at $50 \mathrm{nM}$ induced all five of the Bcr$\mathrm{Abl}^{+}$leukemic cell lines that we examined to die regardless of the p53 expression (Figure 1a, b and Supplementary Figure 1). All cell lines underwent apoptotic cell death as determined by the presence of typical apoptotic morphology (Figure 1cii, dii, and data not shown), loss of MOMP (Figure 2a and data not shown), DNA fragmentation, and accumulation of the cells in the subG1 phase (Figure 2b, $c$ and data not shown). As the INNO-406-induced cell death in the lines was invariably accompanied with caspase-3 activation (Figure $2 d$ and data not shown), we next examined whether blocking caspase activity would inhibit INNO-406-induced cell death. Although caspase-3 activity was effectively blocked by zVAD-fmk (zVAD), a pan-caspase inhibitor pretreatment (Figure 2d and data not shown), it failed to completely abolish the INNO406-induced cell death (Figures $1 \mathrm{~b}$ and $2 \mathrm{a}$ ). This was true for all the cell lines we tested but the degree to which zVAD inhibited INNO-406-induced cell death differed depending on the cell line. Indeed, the cell lines could be divided into two types depending on how fast INNO-406 induced cell death in the presence of $z V A D$ : the K562, KT-1 and BV173 lines showed a marked delay in cell death whereas the cell death of the $\mathrm{MYL}$ and $\mathrm{Ba} / \mathrm{F} 3 / \mathrm{bcr}-a b / /$ wt lines was only marginally retarded (Figure 1b). Thus, INNO-406 can induce cell death by both caspase-mediated and caspase-independent pathways, and the dependence on caspase activity varies depending on the leukemic cell clone.

In the caspase-inactive condition, INNO-406 kills $\mathrm{Bcr}-\mathrm{Abl}^{+}$leukemic cell lines by two distinct mechanisms. As indicated above, the INNO-406-induced cell death that took place when caspase activity was intact was shown to be apoptosis, as determined by the presence of typical morphologic changes (such as cell shrinkage, nuclear condensation and nuclear fragmentation) and DNA fragmentation (Figure $2 \mathrm{~b}$ and $\mathrm{c}$ ), followed by necrotic changes, which are morphologically characterized by cell swelling or rupture of cytoplasmic membrane, so-called 'secondary necrosis' (Figure 1civ and diii). This is consistent with previous observations. ${ }^{4,14}$ Next we investigated the cell death pathways that are induced in each cell line by INNO-406 under caspase-inactive conditions. We found that ZVAD-pretreated and INNO-406treated K562, KT-1 and BV173 cells (i.e. the three cell lines whose killing by INNO-406 was strongly inhibited by zVAD pretreatment) underwent cell death associated with morphologic changes that are inconsistent with apoptosis but consistent with CIND, namely, the presence of cell shrinkage and non-fragmented nuclei with partial condensations (Figure $1 \mathrm{C}$ and data not shown). ${ }^{12,15,19}$ These changes were not accompanied by DNA fragmentation or the accumulation of subG1 cells (Figure 2b). Thus, the cell death mechanism utilized by $\mathrm{K} 562, \mathrm{KT}-1$ and BV173 is distinct from caspase-dependent apoptosis and is likely to be CIND (Figure 2b). In contrast, MYL and $\mathrm{Ba} / \mathrm{F} 3 / \mathrm{bcr}$-abl/wt exhibited a typical apoptotic appearance and DNA fragmentation in both the presence and absence of caspase activity (Figures $1 \mathrm{~d}$ and $2 \mathrm{c}$ ), which indicates that INNO-406 induced CIA in these cell lines. Significantly, the CIND and CIA mechanisms utilized by the lines after co-treatment with INNO-406 and ZVAD were both blocked by the overexpression of $\mathrm{Bcl}-2$ protein (Figure $2 \mathrm{e}$ and data not shown). This indicates that both pathways are mitochondria-mediated PCD (Table 1).

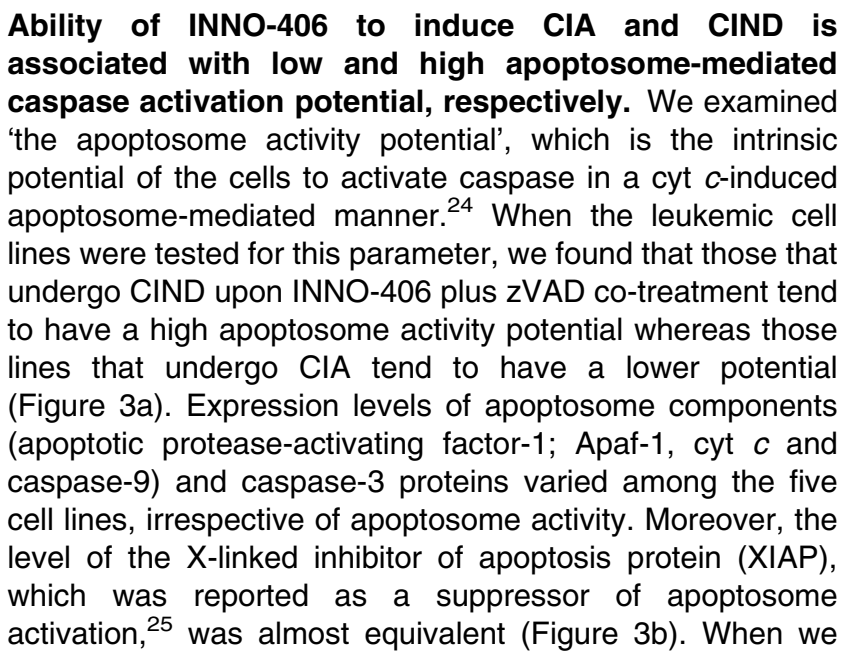




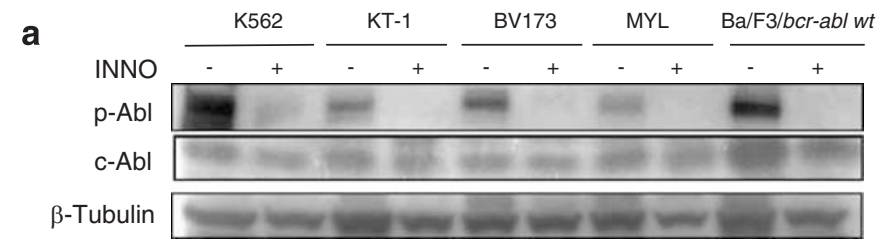

b
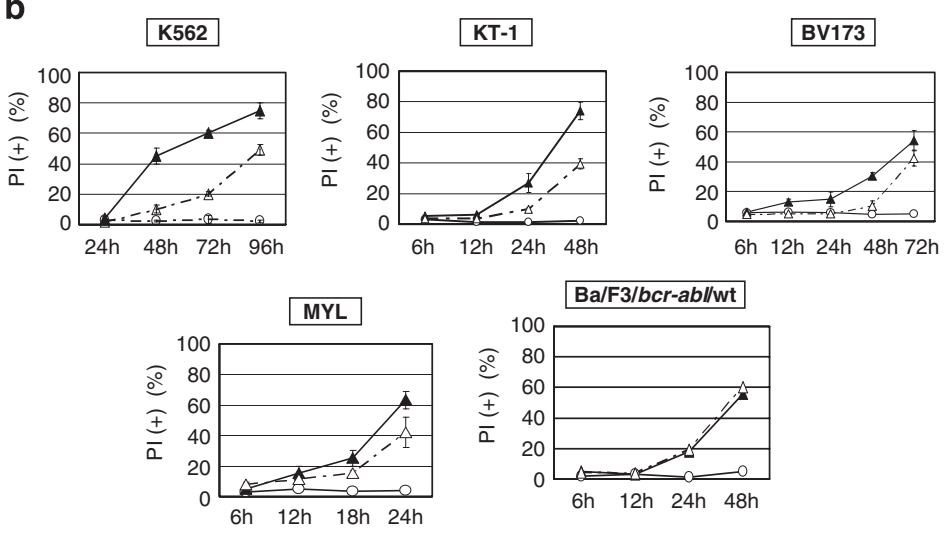

c
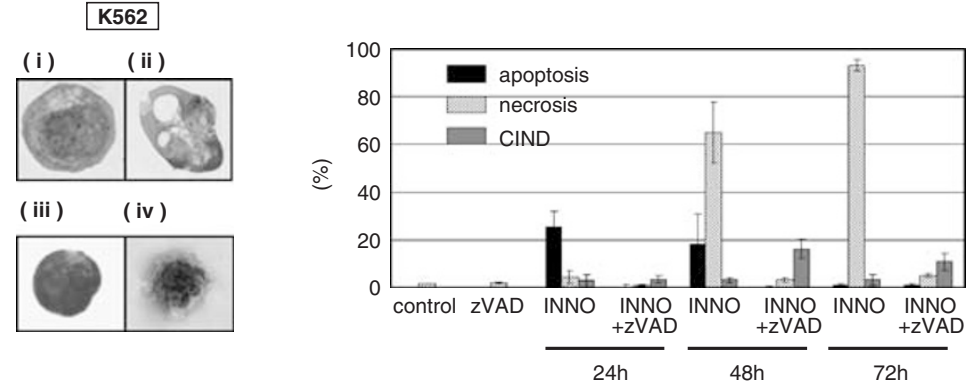

d $M$
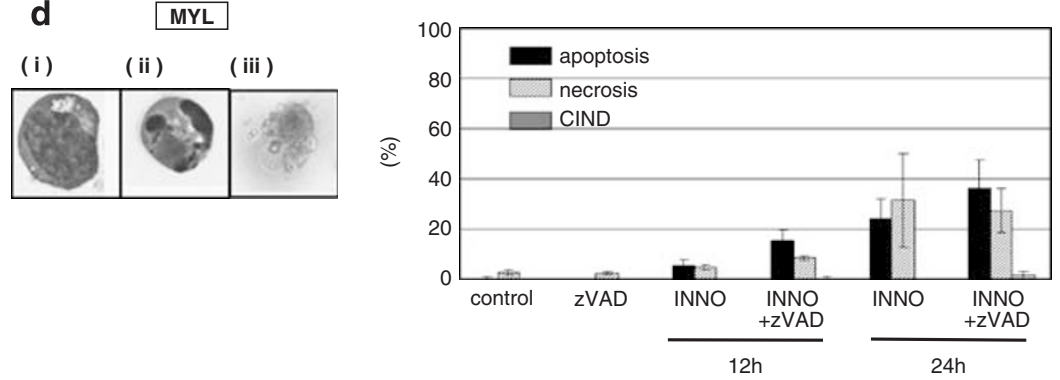

Figure 1 INNO-406 induces caspase-mediated and caspase-independent cell death in Bcr-Abl ${ }^{+}$leukemia cell lines. (a) WB analysis to detect phosphor (p)-Bcr-Abl, c-Abl and $\beta$-tubulin in leukemic cell lines that have been treated with $(+)$ or without $(-) 50 \mathrm{nM} \mathrm{INNO}-406$ for $24 \mathrm{~h}$. (b) The viability of leukemic cell lines after treatment with $(\mathbf{\Lambda})$ and without $50 \mathrm{nM} \mathrm{INNO-406}(\mathrm{O})$, or with INNO-406 plus $50 \mu \mathrm{M}$ zVAD pretreatment $(\Delta)$ was determined by measuring the cellular incorporation of propidium iodide (PI). zVAD alone did not induce cell death (data not shown). The dead cell ratios for each cell line at the indicated periods are shown. The data of three independent experiments are expressed as means \pm S.D. (c, d) Light microscopy (LM) analysis of K562 and MYL cells, respectively, after their treatment with $50 \mathrm{nM}$ INNO-406 in the presence or absence of $50 \mu \mathrm{M}$ zVAD pretreatment. Morphology of untreated healthy K562 cell (ci), apoptotic cell (cii), cell undergoing CIND (ciii), necrotic cell (civ), untreated healthy MYL cell (di), apoptotic cell (dii), and necrotic cell (diii). The frequencies of apoptotic, necrotic, or CIND cells were shown (Bar figures in c, d). The data of three independent experiments are expressed as means \pm S.D.

tested nine freshly isolated leukemic cell samples from Bcr$\mathrm{Abl}^{+}$leukemia patients, we found that they also had either low or high apoptosome activity potential (Figure 3c). These results indicate that leukemic cells that produce a CIND response upon INNO-406 treatment under caspase-inactive conditions have a high apoptosome activity potential, whereas a CIA response is associated with a low potential, and moreover, the PCD response triggered by INNO-406 treatment varies depending on the $\mathrm{Bcr}^{-\mathrm{Abl}}{ }^{+}$leukemia cell clone. Neither decrease of apoptosome component factors nor XIAP expression level of cells was correlated with these tendencies.

INNO-406 induces autophagy in caspase-inactive conditions, particularly in cells that undergo CIND. We sought to further characterize the apoptotic and CIND 
a
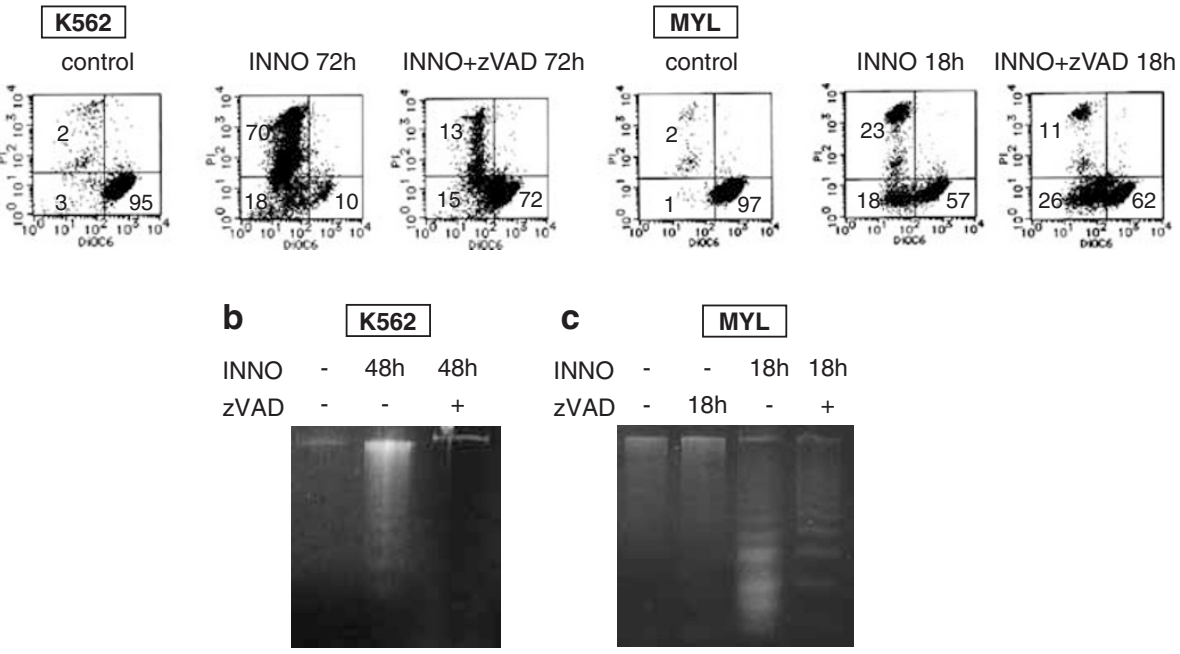

\section{C}

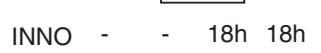

zVAD
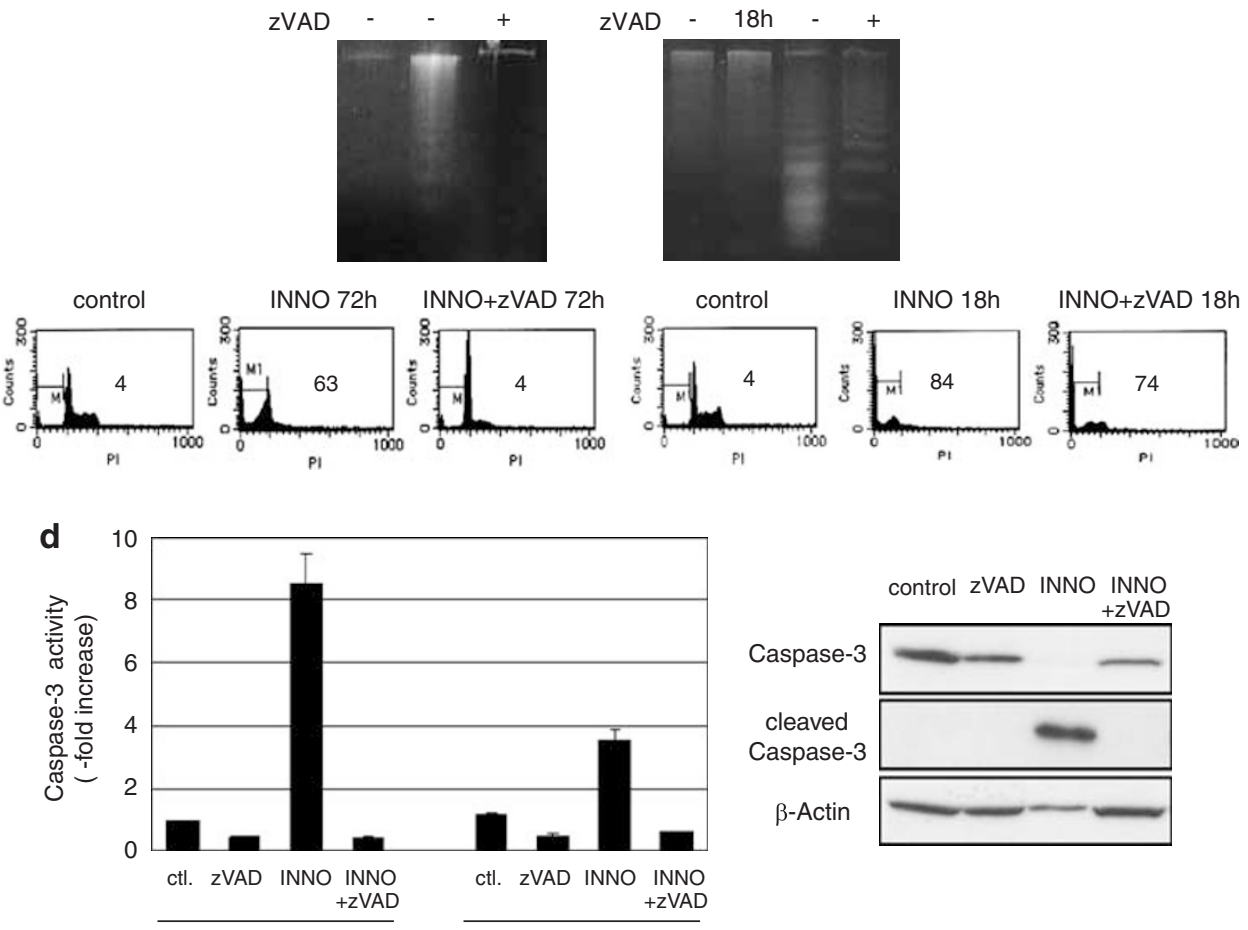

$48 \mathrm{~h}$
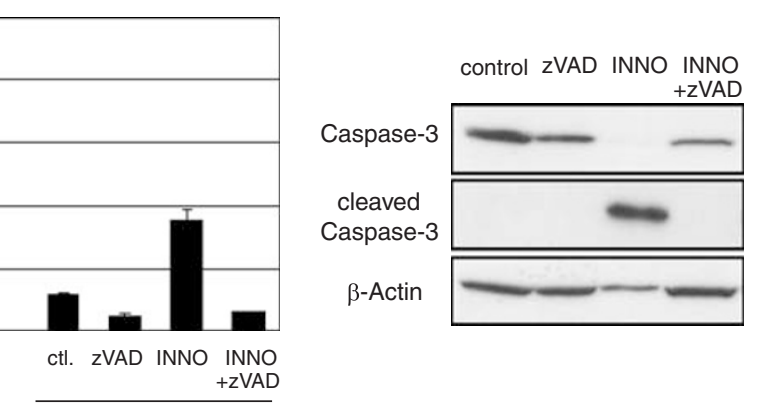

e
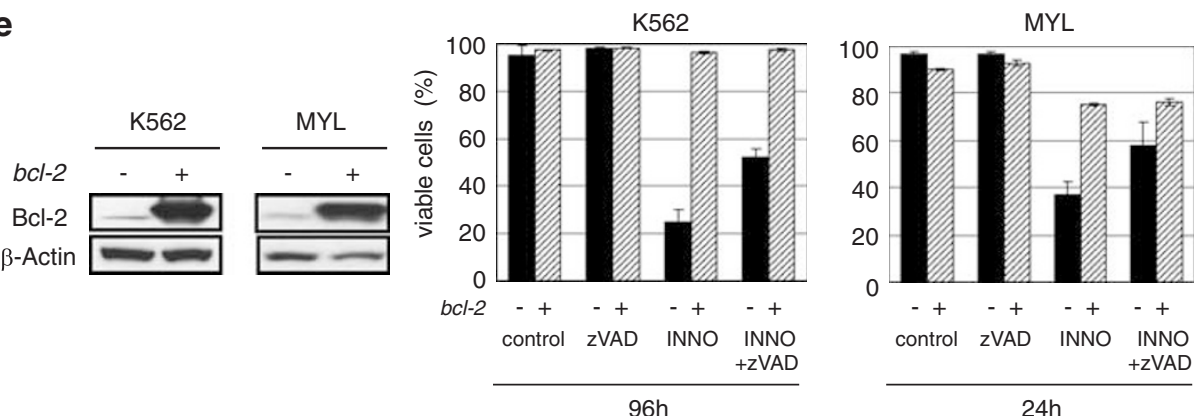

Figure 2 INNO-406 kills Bcr-Abl ${ }^{+}$leukemic cell lines by two distinct mechanisms in the caspase-inactive condition. (a) Flow cytometric analysis of leukemic cell lines that have been treated with $50 \mathrm{nM}$ INNO-406 in the presence or absence of $50 \mu \mathrm{M} \mathrm{zVAD}$ pretreatment for the indicated period. The cells were simultaneously stained with 3,3'dihexyloxacarbocyanine iodide (DiOC6(3)) to determine the mitochondrial transmembrane potential and PI to detect cell death. Representative results of K562 (left) and MYL (right) are shown. (b, c) The presence of internucleosomal DNA fragmentation in the zVAD- and/or INNO-406-treated leukemic K562 and MYL cells, respectively, was assessed by performing a DNA ladder study and by flow cytometric analysis of the PI-stained cells to determine their DNA content. The frequencies of the cells in the subG1 phase are indicated. (d) Leukemic K562 cells were treated with or without INNO-406 and/or ZVAD. (Left) The caspase-3 activity in the cells was measured by determining the cleavage of the DEVD-AFC substrate. The data of three independent experiments are shown as mean \pm S.D. fold-increase relative to the activity in the untreated cells. (Right) The effect of INNO-406 on the processing of pro-caspase-3 to caspase-3 was determined by WB analysis. (e) (Left) WB analysis of Bcl-2 expression in parental K562, K562/ $b c l-2$, parental MYL and MYL/bcl-2. (Right bar figures) Parental K562, K562/bcl-2, parental MYL and MYL/bcl-2 were treated with 50 nM INNO-406 for the indicated periods and/or with $50 \mu \mathrm{M} z \mathrm{VAD}$. Cell viability ratios were determined. The results of three independent experiments are shown as means \pm S.D. 
Table 1 Types of caspase-independent cell death induced by INNO-406 in different leukemic cell lines

\begin{tabular}{|c|c|c|c|c|c|}
\hline Cell line & K562 & KT-1 & BV173 & MYL & Ba/F3/bcr-abl/wt \\
\hline Apoptotic morphology & - & - & - & + & + \\
\hline DNA ladder/accumulation of subG1 fraction & - & - & - & + & + \\
\hline Speed of cell death execution ${ }^{a}$ & Delayed & Delayed & Delayed & Unchanged & Unchanged \\
\hline MOMP & + & + & + & + & + \\
\hline Protection by $\mathrm{Bcl}-2$ overexpression & + & NE & NE & + & + \\
\hline LC3-II formation & + & + & + & + & + \\
\hline Mode of cell death & CIND & CIND & CIND & $\mathrm{CIA}$ & $\mathrm{CIA}$ \\
\hline
\end{tabular}

CIA, caspase-independent apoptosis; CIND, caspase-independent necrosis-like cell death; NE, not examined ${ }^{\mathrm{a}} \mathrm{The}$ speed of cell death execution with zVAD pretreatment was compared with the speed of cell death execution without ZVAD (Figure 1b)

responses that are induced by INNO-406 by performing electron microscopy (EM) study on zVAD-pretreated and/or INNO-406-treated K562 (Figure 4a) and KT-1 cells (Supplementary Figure 2A). INNO-406 alone induced the classical features of apoptosis, namely, the presence of darkened, fragmented nuclei. In contrast, cells undergoing CIND exhibited dispersed foci of chromatin condensation, heterochromatin and darkened nuclei. Significantly, they also exhibited extensive cytoplasmic vacuolation, autophagosomes and autophagic vacuoles containing membrane whorls, all of which seemed to consist with autophagic response.

To confirm that zVAD-pretreated and INNO-406-treated leukemic cells undergo autophagy, we used western blotting (WB) analysis to detect isoforms of the Light chain 3 (LC3)-II membrane protein, which is only present when cells form an autophagosome. $^{26}$ For all five cell lines, exposure to both ZVAD and INNO-406 indeed induced the cytoplasmic accumulation of LC3-II, whereas this was not observed when the cells had been treated with either INNO-406 or zVAD alone (Figure $4 \mathrm{~b}$ and Supplementary Figure $2 \mathrm{~B}$ ). Although LC3-Il was detected in all five cell lines, we could not morphologically detect any autophagic cells in CIA-prone cell lines, MYL and Ba/F3/bcr-abl/wt (Figure 1d and data not shown). An immunofluorescent (IF) study also revealed that INNO-406 and ZVAD co-treatment resulted in punctate LC3 fluorescence, which indicates the formation of autophagosomes and autophagolysosomes in the cytoplasm (Figure 4c, Supplementary Figure $2 \mathrm{C}$ and data not shown). Again, this was only observed in the cells that were treated with both INNO-406 and ZVAD. Thus, CIND-prone cell lines show autophagic response by INNO-406 only when caspase has been inactivated.

INNO-406-induced autophagy protects cells from cell death. To ascertain the role played by INNO-406-induced autophagy in caspase-inactive conditions, we sought to block autophagy by using $C Q$. $C Q$ is a lysosomotropic drug that raises the intralysosomal $\mathrm{pH}$ and impairs autophagic protein degradation and is frequently used to inhibit autophagy. ${ }^{20,27}$ When K562, KT-1 and BV173 were tested, CQ treatment significantly enhanced the cell death induced by treatment with INNO-406 both alone and in combination with ZVAD (Figure 5a, Supplementary Figure 3B and data not shown). The cell death observed with CQ, INNO-406, and zVAD co-treatment had no apoptotic features (Figures 5b, c and Supplementary Figure $3 \mathrm{C}$ and $\mathrm{D}$ ). Instead, there was a significant increase of 'vacuolated cells', which have multiple vacuoles, indicating the accumulation of ineffective autophagosomes. $^{21}$ These vacuolated cells underwent secondary necrosis after a time (Figure $5 d$, Supplementary Figure 3A). CQ treatment caused accumulation of LC3-II, which indicates effective impairment of autophagy by $\mathrm{CQ}$ (Supplementary Figure 3E). Treatment with 3-MA, ${ }^{27}$ another autophagy inhibitor, also enhanced the cell death in these three cell lines (Supplementary Figure 3F and data not shown). Furthermore, shRNA analysis was used to knockdown beclin1, an autophagy-specific gene, in K562 cells. Although the transfection efficiency was partial, cell death was significantly enhanced in shBeclin1 RNA-transfected cells (Supplementary Figure 4A and B). These results suggest that INNO-406-induced autophagy is a protective response to delay cell death execution in K562, KT-1 and BV173 cells.

Unlike the CIND-prone cell lines, cotreatment with $C Q$ did not show any significant effect on MYL and Ba/F3/bcr-abl/wt cells (Supplementary Figure 5A, B and data not shown). Although LC3-II was detected in these cell lines (Supplementary Figure 2B), we could not morphologically detect any autophagic cells (Figure 1d and data not shown). Taken together, these cell lines have little, if any, utilization of this protective autophagic mechanism.

In vivo INNO-406 treatment induces primary $\mathrm{Bcr}^{-\mathrm{Abl}}{ }^{+}$ leukemic cells to undergo cell death regardless of the activity status of caspase. Our observations prompted us to investigate how INNO-406 actually kills primary Bcr-Abl ${ }^{+}$ leukemic cells in the clinical setting. As a model of the clinical setting, immunodeficient NOD/SCID mice were xenografted with patient-derived $\mathrm{Bcr}-\mathrm{Abl}^{+}$leukemic cells. When the peripheral blood (PB) of the mice indicated massive systemic infiltration with leukemic cells (Supplementary Figure $6 \mathrm{~A}$ and $\mathrm{B}$ ), the mice were treated with INNO-406 (or vehicle). In the spleen and bone marrow (BM) of the INNO406-treated mice, we found dying cells with abnormal nuclear structures (Figure 6a and b) such as the apoptotic bodies, fragmented nuclei, or condensed necklace-like nuclei that characterize the early stage of nuclear fragmentation that takes place during apoptotic execution, ${ }^{28}$ and also CIND-like cells. These dying cells were rarely observed in untreated 


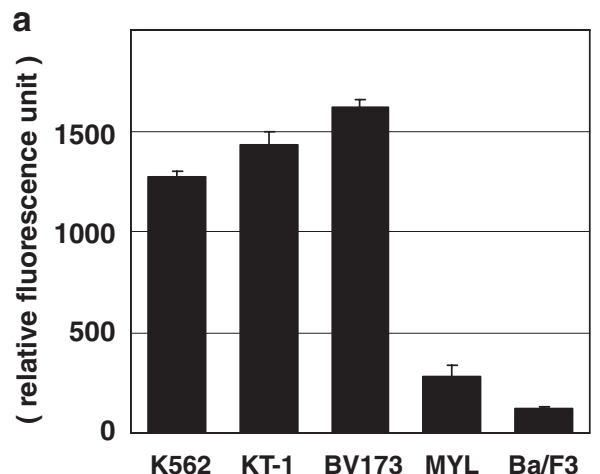

b $\mathrm{K} 562 \mathrm{KT}-1 \quad \mathrm{BV} 173 \mathrm{MYL} \mathrm{Ba} / \mathrm{F} 3$
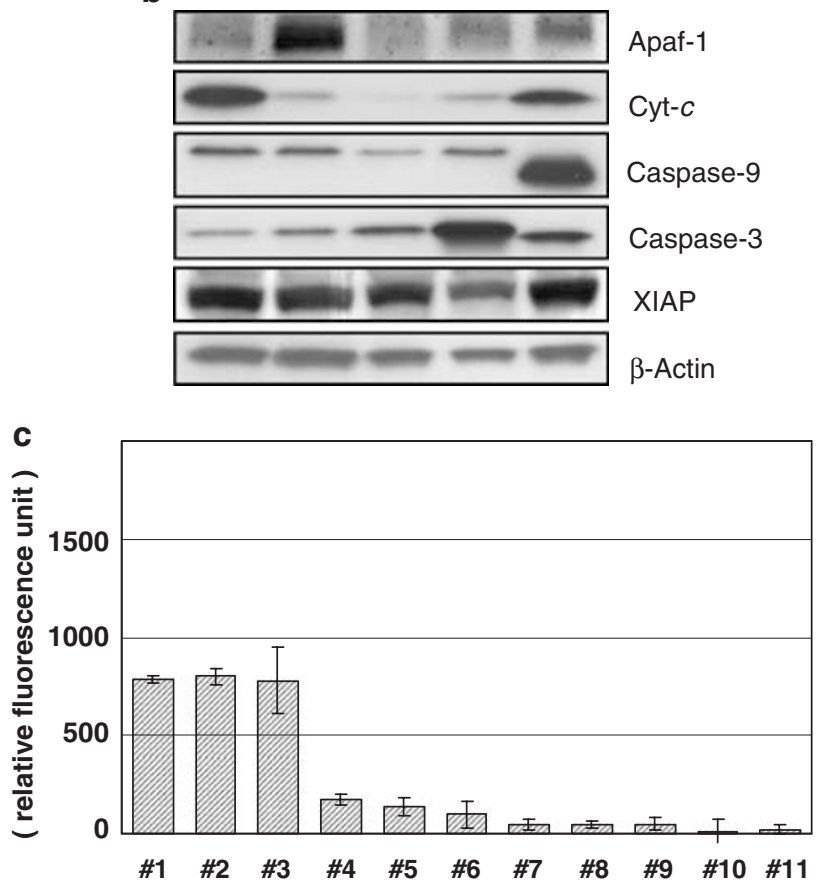

Figure 3 The apoptosome activity potential of $\mathrm{Bcr}-\mathrm{Abl}^{+}$leukemic cells. (a) Measurement of the intrinsic potential for apoptosome-mediated caspase-3 activation in untreated Bcr-Abl ${ }^{+}$leukemic cell lines. (b) WB analysis of apoptosome component factors (Apaf-1, cyt $c$ and caspase-9), caspase-3 and XIAP among untreated Bcr-Abl ${ }^{+}$leukemic cell lines. (c) The apoptosome activity potential of Bcr$\mathrm{Abl}^{+}$primary leukemic cells and healthy volunteers. The patient details are as follows: untreated $\mathrm{Ph}^{+} \mathrm{ALL}$ with E255K mutation in Bcr-Abl (Bcr-Abl ${ }^{\mathrm{E} 255 \mathrm{~K}}$ ) (no. 1): untreated $\mathrm{Ph}^{+} \mathrm{ALL}$ without mutations (no. 2); imatinib-refractory CML chronic phase without mutations (no. 3); imatinib-refractory $\mathrm{Ph}^{+} \mathrm{ALL}$ with $\mathrm{Bcr}-\mathrm{Abl}{ }^{\top 3151}$ (no. 4); imatinib-refractory $\mathrm{CML}$ with $\mathrm{Bcr}-\mathrm{Abl}{ }^{\mathrm{E} 255 \mathrm{~K}}$ ( no. 5); imatinib-refractory $\mathrm{CML}$ with Bcr-AbIE255 K (no. 6); untreated CML chronic phase (nos. 7-9); healthy volunteers (nos. 10, 11)

mice (data not shown) and proved to be the transplanted human leukemic cells, as determined by their reactivity to anti-human CD45 antibody (Figure 6a and b). Notably, these cells were not always reactive with the antibody against cleaved caspase-3 (Figure 6c) and cleaved caspase-9 (Supplementary Figure 6C). The percentage of cleaved caspase-3-negative cell of all dying cells in human $\mathrm{Bcr}^{-\mathrm{Abl}}{ }^{+}$ leukemic cells xenografted mouse followed by INNO-406 treatment was $54 \%$ (spleen) and $71 \%$ (BM) (Figure 6c), which suggest that caspase- 3 and -9 activation is not necessary for the ability of INNO-406 to induce patient-derived leukemic cells to undergo cell death in vivo, or rather caspase-independent cell death is a major contributor to the in vivo response to INNO-406.

\section{Discussion}

Here we investigated the cell death mechanism that is elicited in Bcr-Abl ${ }^{+}$leukemias by the Bcr-Abl TK inhibitor INNO-406. It was previously believed that Bcr-Abl TK inhibitors induce $\mathrm{Bcr-Abl}{ }^{+}$leukemias to undergo caspase-mediated apoptosis, mainly through mitochondria-mediated intrinsic apoptosis. ${ }^{15,16}$ Indeed, we found in our study that INNO-406 induced the leukemic cells we tested to become apoptotic and that this was p53-independent (Supplementary Figure 1), and accompanied with caspase activation. However, we then found by pretreating the cells with the pan-caspase inhibitor zVAD that INNO-406 can also induce two distinct mechanisms of caspase-independent PCD, namely, delayed CIND or CIA. Notably, the leukemic cell lines varied regarding which of these alternative cell death pathways were triggered by INNO406, as K562, KT-1 and BV173 underwent CIND whereas MYL and $\mathrm{Ba} / \mathrm{F} 3 /$ bcr-abl/wt died by CIA (Table 1 ).

These observations are of interest because they suggest that drugs such as INNO-406 may be useful in situations where the normal caspase-dependent apoptotic response to antitumor drugs has become impaired. This may happen if caspase becomes inactivated, which has been shown to occur in cancer cells by various mechanisms. These include the endogenous expression of inhibitors of apoptosis proteins (IAPs) such as XIAP. ${ }^{29}$ Indeed, the expression of the IAP survivin has been linked to $\mathrm{CML}$ disease progression and apoptosis resistance, although it remains unclear whether this molecule truly functions as a caspase inhibitor. Caspase pathways can be inactivated by mutations, energy depletion, nitrative/oxidative stress, or the simultaneous activation of other proteases. ${ }^{13,30}$ Procaspase- 9 activation within the apoptosome are also inhibited by release of low mass iron by lysosomal rupture. ${ }^{31}$ Thus, that INNO-406 can trigger caspase-independent PCD as well as caspase-dependent apoptosis may point to new therapeutic avenues for $\mathrm{Bcr}-\mathrm{Abl}{ }^{+}$ leukemias. These observations may have ramifications for the treatment of other cancerous diseases as well.

As previously reported, INNO-406 shuts down Bcr-Abl and upregulates several $\mathrm{BH}$-only proteins, such as Bim, Bad, Bmf and Bik, ${ }^{32}$ followed by MOMP, which is known as 'the point of no-return' for cell death commitment. ${ }^{10,33}$ As INNO-406 inhibits Bcr-Abl signaling as imatinib does, these events probably occur through shutdown of the downstream of Bcr-Abl signaling pathway, signal transducer and activator of transcription and phosphoinositide-3-kinase (PI3K)/Akt pathways. MOMP induces the release of toxic mitochondrial molecules such as cyt $c$ into the cytosol. Cyt $c$ forms a complex with Apaf- 1 and pro-caspase- 9 that is called the 'apoptosome'. This complex first promotes caspase- 9 processing and then amplifies the proteolytic activities of the downstream caspase cascades. ${ }^{34}$ It was recently observed that tumor cells vary in terms of their apoptosome activity potential, and that inactivation of the apoptosome is a cause of chemoresistance and oncogenic transformation. ${ }^{24,35,36}$ The 


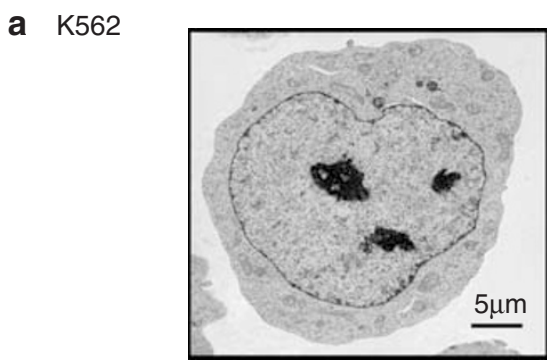

control

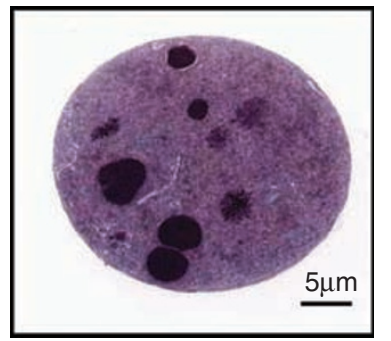

INNO-406

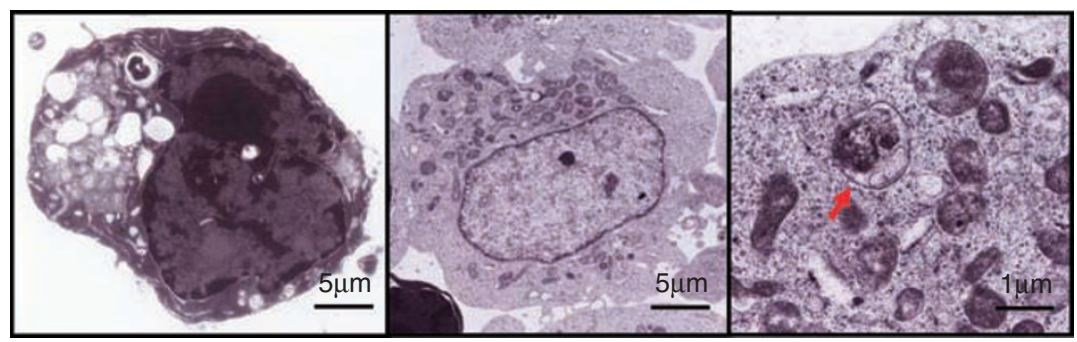

INNO-406 + zVAD
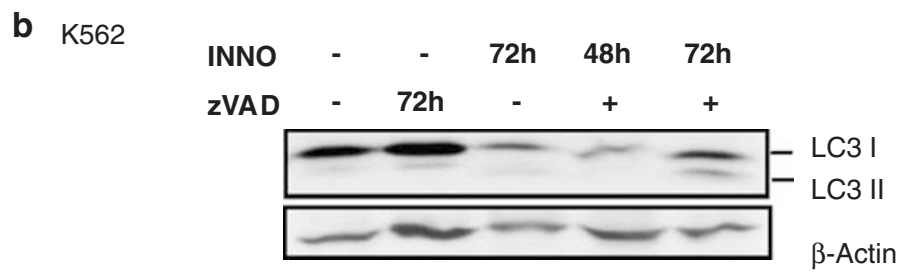

C $\mathrm{K} 562$

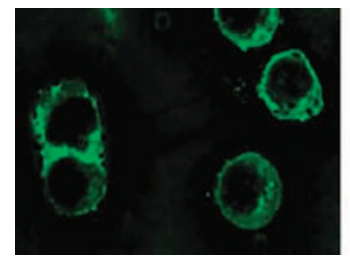

control

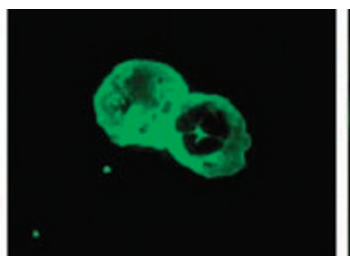

INNO-406

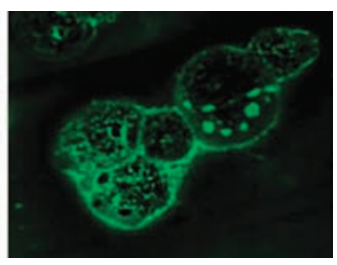

INNO-406 + zVAD

Figure 4 Autophagy induced by INNO-406 in K562 cells under the caspase-inactivated condition. (a) EM analysis of K562 cells treated with INNO-406 for $48 \mathrm{~h}$ in caspaseactive or -inactive conditions. In INNO-406- and zVAD-treated cells, heterochromatin, extensive cytoplasmic vacuolation, autophagosomes, and/or autophagolysosomes with dark inclusions or whorl membranous structures were detected (arrow). (b, c) WB (b) and IF (c) analysis for LC3 of K562 cells. LC3-II isoform was detected in INNO-406- and zVAD-treated cells at the $72 \mathrm{~h}$ time point. (b) INNO-406 treated K562 cells with or without ZVAD for $48 \mathrm{~h}$. A punctated dotted pattern of LC3 staining was detected in the ZVADpretreated and INNO-406-treated cells (c)

expression of XIAP, and defective p53 molecules have been reported to inhibit the apoptosome. ${ }^{24,37}$ It is believed that the natural cell death pathways are altered in apoptosomedefective cells. Therefore, to overcome chemoresistance, it may be useful to develop agents that can trigger another cell death pathway, such as a caspase-independent pathway. ${ }^{24}$ However, it remains unclear how the cell death patterns are altered in apoptosome-defective tumor cells. Here, we show for the first time that low-potential apoptosome activity in Bcr$\mathrm{Abl}^{+}$leukemic cells is associated with a predisposition to generate a CIA response to INNO-406, whereas a high potential apoptosome activity is associated with a tendency to produce a CIND response. We reasoned that INNO-406 induces CIND in some leukemic cell lines but CIA in others because these cell lines vary in their degree of clonal transformation, in particular with regard to transformation events that affect apoptosome activity. It should be noted that the CML cell lines we used here were all derived from patients with the most advanced clinical phase of CML (CML-BC). The cells from these patients are thus likely to have experienced a high degree of clonal evolution involving the acquisition of various genetic mutations. Indeed, in the $\mathrm{Bcr}-\mathrm{Abl}^{+}$leukemic cell lines that had a high apoptosome activity potential, INNO406-induced apoptotic cell death was effectively protected by zVAD, which suggests the high dependency on apoptosomemediated caspase apoptotic cell death pathway (Figures 1b, $c$ and $3 a$ ). Consistent with this was that the zVAD-mediated caspase inhibition had only a marginal effect on the cell lines with lower apoptosome activity, which rapidly entered CIA upon INNO-406 treatment (Figures 1b, d and 3a). To evaluate 

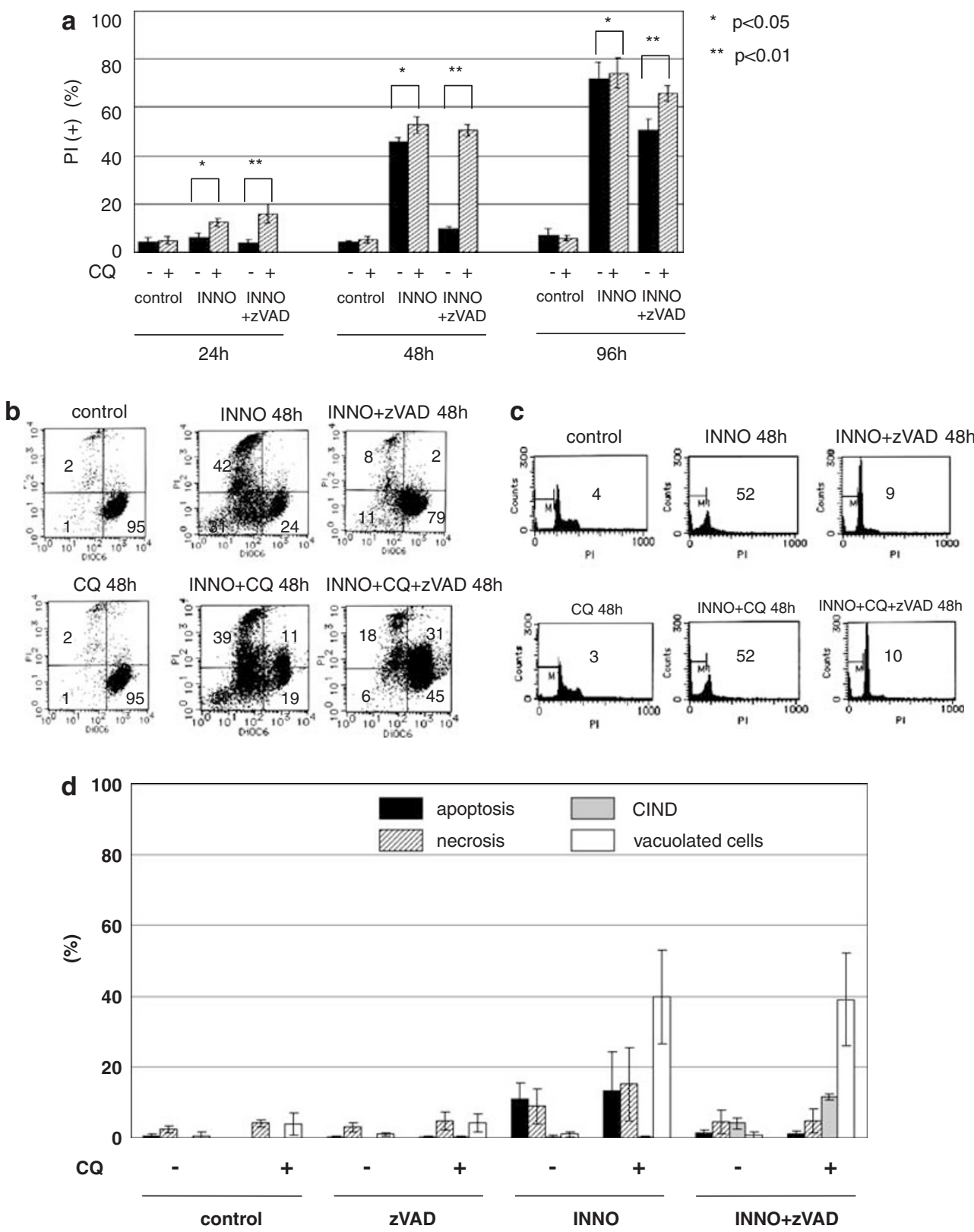

Figure 5 CQ enhanced the cell death induced by INNO-406 with or without ZVAD in K562 cells. (a) Effect of $10 \mu \mathrm{M} \mathrm{CQ}$ pretreatment on K562 cell death induced by $50 \mu \mathrm{M}$ zVAD-pretreatment and/or $50 \mathrm{nM}$ INNO-406 treatment. Cell death was revealed by the incorporation of PI. Dead cell ratios at the indicated periods are shown. The data of three independent experiments are expressed as means \pm S.D. (b) Flow cytometric analysis of K562 cells treated as described in (a). The cells were simultaneously stained with DiOC6(3) and PI. (c) Flow cytometric analysis of K562 cells treated as described in (a). Internucleosomal DNA fragmentation was assessed by PI staining and flow cytometric analysis for DNA content. The frequencies of subG1 cells are indicated. (d) LM analysis of K562 cells treated as described in (a). The frequencies of apoptotic, necrotic, CIND, or vacuolated cells at the $24 \mathrm{~h}$ time point are shown. The data of three independent experiments are expressed as means \pm S.D.

the key mediator of this $\mathrm{ClA}$, we examined Omi/Htra2 and apoptosis-inducing factor (AIF). Omi/Htra2 was not released into the cytosol, and AIF was not transferred to the nucleus (data not shown), so that these mediators were not related with this CIA.

Significantly, the intrinsic apoptosome-mediated caspase-3 activation potential in patient-derived $\mathrm{Bcr}-\mathrm{Abl}^{+}$leukemic cells also varied (Figure $3 \mathrm{c}$ ). Although it remains unclear why such differences in apoptosome activity potentially exist, these observations suggest that different cell types may vary in their dependence on the caspase-mediated pathway for apoptosis, and that this diversity may underlie the mode of caspaseindependent PCD that is triggered by INNO-406 upon caspase inactivation. It should also be noted that when we xenografted NOD/SCID mice with $\mathrm{Bcr}-\mathrm{Abl}^{+}$leukemic cells from various CML/ALL patients, INNO-406 successfully induced cell death in the leukemic cells even though caspase was not activated in many cases (Figure 6c). Recent reports also support the concept of caspase-independent cell death in vivo. ${ }^{38,39}$ This observation demonstrates that caspase- 
a

HE

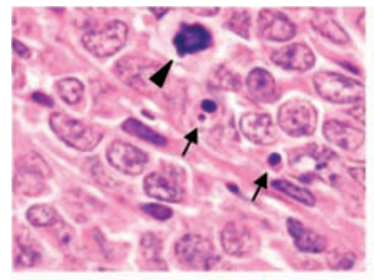

Spleen
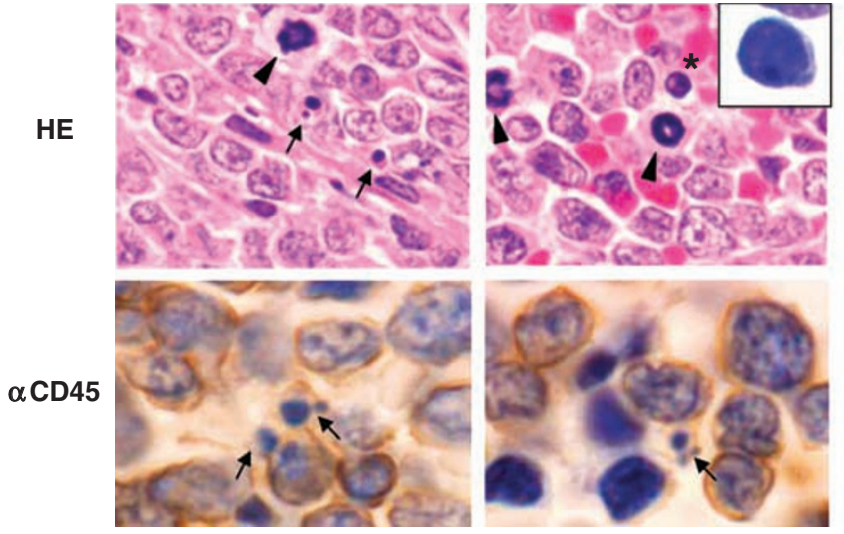

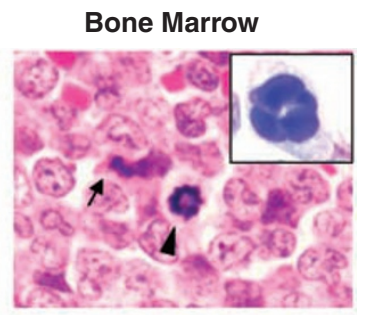

b

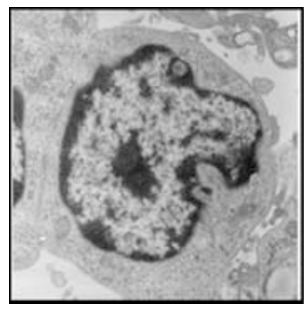

untreat
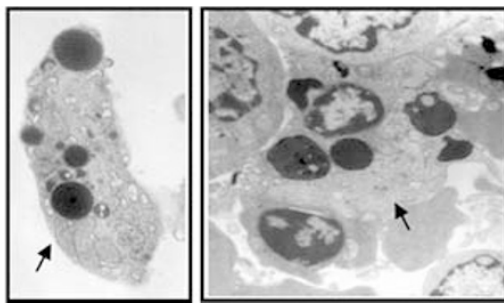

INNO-406

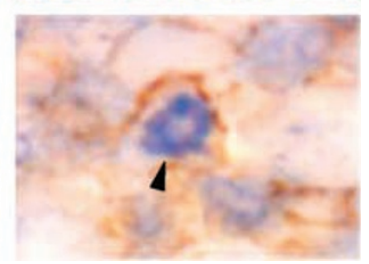

C
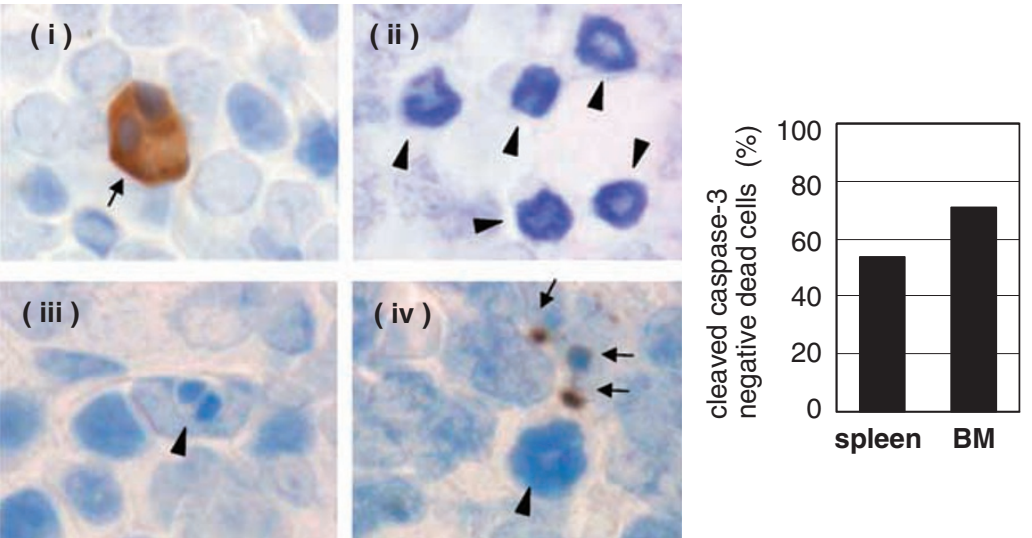

Figure 6 Effects of INNO-406 in mouse model of primary human Bcr-Abl ${ }^{+}$leukemic cells. (a) Histological and immunohistochemical (IHC) analysis of the spleen and BM of a NOD/SCID mouse that had been xenografted with human Bcr-Abl ${ }^{+}$leukemic cells and then treated with INNO-406. Hematoxilin-Eosin (HE) staining revealed apoptotictype nuclei, such as a necklace-like nucleus (arrowhead), fragmented apoptotic bodies (arrow), and CIND-like cells (asterixis). These dying cells proved to originate from human leukemic cells, as shown by their reactivity to anti ( $\alpha$ )-human CD45 antibody. (b) EM analysis of the leukemic cells in the xenografted and INNO-406-treated mice. Features characteristic of apoptotic cells were observed, including the presence of heterochromatin, apoptotic bodies, fragmented nuclei, and condensed necklace-like nuclei. (c) IHC analysis of the caspase activity in the leukemic cells from the xenografted and INNO-406-treated mice. The cells were stained with anticleaved caspase-3 antibody. Not all apoptotic leukemic cells were reactive to this antibody. (Left) Dead cells in (ii-iv) (arrowhead) were unreactive cells. (Right bar figure) Cleaved caspase-3-negative dead cells of spleen and BM were quantified

independent cell death may play an important role in the clinical setting. These observations together also suggest that previous studies on CML cell lines may have overestimated the role caspases play in the apoptosis induced by Bcr-Abl TK inhibitors.

Prior studies have led to conflicting views regarding the role played by autophagy. In some settings, it has been reported as a type-2 PCD process (autophagic cell death) but in others it appears to serve as a mechanism that protects the cell in energy-insufficient conditions. ${ }^{20-23,25}$ In our study, we found that cells undergoing INNO-406-induced CIND showed pronounced autophagy (Figure 4, Supplementary Figure 2 and data not shown) whereas the cells undergoing CIA showed more limited autophagy, which was detected only by LC3-II (Supplementary Figure 2B). Thus, autophagy appears to play a significant role in CIND but not in CIA. This led to the question, does autophagy underlie the CIND cell death process or is it a protective response? To answer this question, we sought to block autophagy by $\mathrm{CQ}, 3-\mathrm{MA}^{20,27}$ and shBeclin1 RNA transfection. Autophagy inhibition significantly enhanced cell death in the CIND-prone cell lines rather than reducing the CIND response to INNO-406 
(Figures 5 and Supplementary Figures 3 and 4). Thus, INNO406-induced autophagy may be a protective process that is elicited by the cell during the course of INNO-406-induced CIND. It is possible that as the shutdown of Bcr-Abl signaling represents a sort of energy crisis for $\mathrm{Bcr}-\mathrm{Abl}^{+}$leukemias, the activation of autophagy may provide the nutrients necessary for leukemic cells to survive in this scenario. Thus, the pathways that promote autophagy may constitute a novel therapeutic target in CML, particularly for those leukemias that die by CIND in caspase-inactive conditions.

In conclusion, we show that the blockade of Bcr-Abl signaling in $\mathrm{Bcr}-\mathrm{Abl}^{+}$leukemic cells potently induces not just caspase-mediated apoptosis but also the caspase-independent PCD mechanisms, CIND and CIA. Different leukemia cell clones vary in the degree to which caspase is involved in INNO-406-induced PCD as well as in the caspase-independent PCD mechanism that is triggered by INNO-406 in caspase-inactive conditions. Autophagy is likely to serve as a cell preservation system that is activated in $\mathrm{Bcr}-\mathrm{Abl}{ }^{+}$ leukemias when Bcr-Abl signaling is blocked and thus may be a novel therapeutic target in $\mathrm{CML}$.

\section{Materials and Methods}

Cells and reagents. The human leukemic cell lines K562, KT-1, BV173 and MYL were all derived from CML-BC patients. ${ }^{40} \mathrm{Ba} / \mathrm{F} 3 / \mathrm{bcr}$-abl/wt, which expresses wild-type Bcr-Abl, was generated from the murine hematopoietic cell line Ba/F3 as previously described. ${ }^{9} \mathrm{~K} 562$ and MYL sublines that overexpressed human Bcl-2 protein were generated by electroporation followed by WB screening using an antihuman Bcl-2 antibody (Bcl-2-100, Upstate, Lake Placid, NY) to detect high exogenous cytoplasmic Bcl-2 protein levels. ${ }^{5}$ All cells were maintained at $37^{\circ} \mathrm{C}$ under $5 \% \mathrm{CO}_{2}$ in RPMI-1640 containing $2 \mathrm{mM}$ L-glutamine, $10 \%$ heat-inactivated fetal calf serum (Hyclone, UT) and 1\% penicillin/streptomycin antibiotic mixture. INNO-406 was synthesized by Nippon Shinyaku Co. Ltd (Kyoto, Japan). zVAD was purchased from Peptide Institute (Osaka, Japan). PI, CQ and 3-MA were purchased from Sigma Aldrich (St Louis, MO). INNO-406 and ZVAD were dissolved in dimethyl sulfoxide and stored at $-20^{\circ} \mathrm{C}$. $\mathrm{PI}$ and $\mathrm{CQ}$ were dissolved in phosphate-buffered saline and stored at $4{ }^{\circ} \mathrm{C}$. 3-MA was dissolved directly into RPMI-1640. ZVAD was used at $50 \mu \mathrm{M}, \mathrm{CQ}$ was used at $10 \mu \mathrm{M}$ for $\mathrm{K} 562$ and at $5 \mu \mathrm{M}$ for $\mathrm{KT}-1, \mathrm{BV} 713$, MYL and $\mathrm{Ba} / \mathrm{F} 3 / \mathrm{bcr}-a b / \mathrm{wt}$, and $3-\mathrm{MA}$ was used at $10 \mathrm{mM}$. The cells were preincubated with $\mathrm{ZVAD}, \mathrm{CQ}$ and 3-MA for $90 \mathrm{~min}$

Primary Bcr-Abl ${ }^{+}$leukemic cell samples. Studies with human samples were approved by the Ethical Board of the Kyoto University. BM or PB samples were obtained from Bcr-Abl ${ }^{+}$leukemia patients with informed consent. More than $90 \%$ of the leukocytes in the samples were $\mathrm{Ph}^{+}$(as determined by interphase FISH analysis of the presence of the $b c r$-abl fusion gene). The mononuclear cell fraction of the samples was isolated by conventional Ficoll-Paque (Amersham, Uppsala, Sweden) density gradient centrifugation.

Cell death assessment and determination of mitochondrial transmembrane potential $(\Delta \psi \mathrm{m})$. Cell death was defined by the intracellular incorporation of $\mathrm{PI}$, while the mitochondrial transmembrane potential $(\Delta \psi \mathrm{m})$ was measured by FACSCalibur (Becton Dickinson (BD), Franklin Lakes, $\mathrm{NJ}$ analysis after DiOC6(3) (Molecular Probes, Eugene, OR) staining as described. ${ }^{14}$

Morphologic evaluation by light microscopy and electron microscopy. Cells were subjected to cytospin and stained with a Diff-Quick kit (International Reagents, Kobe, Japan), and then examined by light microscopy A minimum of 400 cells was scored for each sample, and the percentage of each morphologic type was determined. Cells were also prepared for electron microscopy analysis with a Hitachi H-7000 electron microscope (Hitachi, Tokyo, Japan) as described previously. ${ }^{14}$

Assessment of internucleosomal DNA fragmentation and DNA content. Internucleosomal DNA fragmentation was analyzed by using
ApopLadder Ex (Takara, Shiga, Japan). For DNA content analysis, the cells were fixed with ice-cold $70 \%$ ethanol and stained with PI. The frequency of subG1 cells was determined by using CellQuest software (BD).

Immunofluorescent staining analysis. Cells were fixed with $4 \%$ paraformaldehyde on a glass slide, blocked with $20 \%$ Block Ace Powder (Dainippon Sumitomo Pharma, Osaka, Japan) with $0.005 \%$ saponin (Sigma) and stained with anti-LC3 antibody (a kind gift from Professor T Yoshimori, Osaka University, Japan) ${ }^{26}$ followed by secondary staining with FITC-conjugated immunoglobulin G (lgG; Santa Cruz Biotechnology, Santa Cruz, CA).

Western blot analysis. Western blot analysis (WB) was performed as described previously. ${ }^{32}$ Antibodies against $\beta$-tubulin (Sigma), $\beta$-actin (Sigma), caspase-3, cleaved caspase-3, caspase-9 (Cell signaling Technology, Beverly, MA), LC3, Apaf-1 (Epitomics Inc, Burlingame, CA), cyt $c$ (BD Pharmingen, San Diego, CA), XIAP (MBL, Nagoya, Japan), p53, c-Abl (Santa Cruz), phosphotyrosine (Upstate) or Beclin1 (Novus Biologicals, Littleton, $\mathrm{CO}$ ) were used.

Measurement of caspase activity. Caspase-3 activity in untreated or INNO-406-treated cells was measured by using a Caspase Fluorometric Protease Assay Kit (MBL) as previously described. ${ }^{14}$

The intrinsic potential in CML cell lines of cyt $c$-induced caspase-3 activation (i.e., the apoptosome activity potential) was also examined as described elsewhere. ${ }^{24}$ Briefly, cytosolic extracts of untreated cells were incubated with $10 \mu \mathrm{M}$ bovine cyt $c$ plus $1 \mathrm{mM}$ dATP (Sigma) for $1 \mathrm{~h}$ and then incubated with $10 \mu \mathrm{M}$ acetyl-Asp-Glu-Val-Asp- (4-metyl-coumaryl-7-amide) (DEVD-MCA) at $37^{\circ} \mathrm{C}$ for $1 \mathrm{~h}$. The release of amino-4-methylcoumarin was monitored by using the Wallac ARVO $S X_{F L} 1420$ Multilabel Counter (excitation, $380 \mathrm{~nm}$; emission, $460 \mathrm{~nm}$ ) (PerkinElmer Life Sciences, Boston, MA)

shRNA transfection. K562 cells were transfected with SureSilencing shRNA plasmid specifically targeting beclin1 RNA with the resistance gene for puromycin (SuperArray, Frederick, MD) using Amaxa nucleofector with solution V, protocol T-03 (Amaxa Biosystems, Gaithersburg, MD). Transfected cells were selected by $5 \mu \mathrm{g} / \mathrm{ml}$ puromycin, and were examined for Beclin1 protein expression by WB analysis.

Mouse model for CML. Male NOD/SCID mice (6-8 weeks of age) were sublethally irradiated ( $2 \mathrm{~Gy}$ ) and $3 \times 10^{6}$ cells from $\mathrm{Ph}^{+} \mathrm{CML}-\mathrm{BC}$ patients were transplanted intravenously into the tail vein as previously described. ${ }^{9}$ The engraftment of the transplanted leukemic cells was certified by flow cytometric analysis that examined the expression of human CD45 in the murine PB. Successfully engrafted mice were randomized into control and treated groups (two mice in each group), and treated with INNO-406 (3 mg per body) or vehicle $(0.5 \%$ methylcellulose) and then sacrificed on the next day. Their BM and spleen were subjected to histological analyses. The experiment was done twice. FITC-conjugated human CD45 and PE-conjugated mouse CD45 antibodies (BD Pharmingen) were used for flow cytometric analysis, and antibodies against cleaved caspase-3, cleaved caspase-9 (Cell Signaling Technology) and human CD45 (Sigma) were utilized for IHC studies.

Acknowledgements. We are grateful to Professor T Yoshimori (Osaka University), Drs T Mashima (Cancer Chemotherapy Center, Japanese Foundation for Cancer Research), DC Huang (The Walter and Eliza Hall Institute of Medical Research), T Heike, YW Lin, Y Toda, M Fujioka, Y Nakagawa (Kyoto University), Y Kobayashi (Kyoto Second Red Cross Hospital), C Shimazaki (Kyoto Prefectural University of Medicine) and $\mathrm{H}$ Segawa (Shiga University of Medical Science) for their technical support, scientific advice, and gifts. This work was partly supported by Grants-in-Aids for Scientific Research from the Ministry of Education, Culture, Sports, Science and Technology of Japan (to TN and TM).

1. Druker BJ, Tamura S, Buchdunger E, Ohno S, Segal GM, Fanning S et al. Effects of a selective inhibitor of the Abl tyrosine kinase on the growth of Bcr-Abl positive cells. Nat Med 1996; 2: 561-566.

2. Melo JV, Deininger MW. Biology of chronic myelogenous leukemia - signaling pathways of initiation and transformation. Hematol Oncol Clin North Am 2004; 18: 545568, vii-viii. 
3. Druker BJ, Sawyers CL, Kantarjian H, Resta DJ, Reese SF, Ford JM et al. Activity of a specific inhibitor of the BCR-ABL tyrosine kinase in the blast crisis of chronic myeloid leukemia and acute lymphoblastic leukemia with the Philadelphia chromosome. $N$ Engl J Med 2001; 344: 1038-1042.

4. Kimura S, Ashihara E, Maekawa T. New tyrosine kinase inhibitors in the treatment of chronic myeloid leukemia. Curr Pharm Biotechnol 2006; 7: 371-379.

5. Kuroda J, Puthalakath $\mathrm{H}$, Cragg MS, Kelly PN, Bouillet P, Huang DC et al. Bim and Bad mediate imatinib-induced killing of $\mathrm{Bcr} / \mathrm{Abl}+$ leukemic cells, and resistance due to their loss is overcome by a BH3 mimetic. Proc Natl Acad Sci USA 2006; 103 14907-14912.

6. O'Brien SG, Guilhot F, Larson RA, Gathmann I, Baccarani M, Cervantes F et al. Imatinib compared with interferon and low-dose cytarabine for newly diagnosed chronic-phase chronic myeloid leukemia. N Engl J Med 2003; 348: 994-1004.

7. Ottmann OG, Druker BJ, Sawyers CL, Goldman JM, Reiffers J, Silver RT et al. phase 2 study of imatinib in patients with relapsed or refractory Philadelphia chromosome-positive acute lymphoid leukemias. Blood 2002; 100: 1965-1971.

8. Druker BJ, Guilhot F, O'Brien SG, Gathmann I, Kantarjian H, Gattermann N, et al., IRIS Investigators. Five-year follow-up of patients receiving imatinib for chronic myeloid leukemia. N Engl J Med 2006; 355: 2408-2417.

9. Kimura S, Naito H, Segawa H, Kuroda J, Yuasa T, Sato K et al. NS-187, a potent and selective dual Bcr-Abl/Lyn tyrosine kinase inhibitor, is a novel agent for imatinib-resistant leukemia. Blood 2005; 106: 3948-3954.

10. Green DR, Kroemer G. The pathophysiology of mitochondrial cell death. Science 2004; 305: $626-629$

11. Kitanaka $C$, Kuchino $Y$. Caspase-independent programmed cell death with necrotic morphology. Cell Death Differ 1999; 6: 508-515.

12. Kroemer G, Martin SJ. Caspase-independent cell death. Nat Med 2005; 11: 725-730.

13. Leist $M$, Jaattela M. Four deaths and a funeral: from caspases to alternative mechanisms. Nat Rev Mol Cell Biol 2001; 2: 589-598.

14. Okada M, Adachi S, Imai T, Watanabe K, Toyokuni SY, Ueno M et al. A novel mechanism for imatinib mesylate-induced cell death of BCR-ABL-positive human leukemic cells: caspase-independent, necrosis-like programmed cell death mediated by serine protease activity. Blood 2004; 103: 2299-2307.

15. Dan S, Naito M, Tsuruo T. Selective induction of apoptosis in Philadelphia chromosomepositive chronic myelogenous leukemia cells by an inhibitor of BCR-ABL tyrosine kinase CGP 57148. Cell Death Differ 1998; 5: 710-715.

16. Fang G, Kim CN, Perkins CL, Ramadevi N, Winton E, Wittmann S et al. CGP57148B (STI-571) induces differentiation and apoptosis and sensitizes Bcr-Abl-positive human leukemia cells to apoptosis due to antileukemic drugs. Blood 2000; 96: 2246-2253.

17. Okada H, Mak TW. Pathways of apoptotic and non-apoptotic death in tumour cells. Nat Rev Cancer 2004; 4: 592-603.

18. Vande Velde C, Cizeau J, Dubik D, Alimonti J, Brown T, Israels S et al. BNIP3 and genetic control of necrosis-like cell death through the mitochondrial permeability transition pore. Mol Cell Biol 2000; 20: 5454-5468.

19. Ertmer A, Huber V, Glich S, Yoshimori T, Erfle V, Duyster J et al. The anticancer drug imatinib induces cellular autophagy. Leukemia 2007; 21: 936-942.

20. Amaravadi RK, Yu D, Lum JJ, Bui T, Christophorou MA, Evan Gl et al. Autophagy inhibition enhances therapy-induced apoptosis in a Myc-induced model of lymphoma. J Clin Inves 2007; 117: 326-336.

21. Boya P, Gonzalez-Polo RA, Casares N, Perfettini JL, Dessen P, Larochette N et al. Inhibition of macroautophagy triggers apoptosis. Mol Cell Biol 2005; 25: $1025-1040$
22. Degenhardt K, Mathew $\mathrm{R}$, Beaudoin B, Bray K, Anderson D, Chen G et al. Autophagy promotes tumor cell survival and restricts necrosis, inflammation, and tumorigenesis. Cancer Cell 2006; 10: 51-64.

23. Tsujimoto Y, Shimizu S. Another way to die: autophagic programmed cell death. Cell Death Differ 2005; 12 (Suppl 2): 1528-1534.

24. Mashima T, Oh-hara T, Sato S, Mochizuki M, Sugimoto Y, Yamazaki K et al. p53-defective tumors with a functional apoptosome-mediated pathway: a new therapeutic target. J Nat Cancer Inst 2005; 97: 765-777.

25. Hait WN, Jin S, Yang JM. A matter of life or death (or both): understanding autophagy in cancer. Clin Cancer Res 2006; 12: 1961-1965.

26. Kabeya Y, Mizushima N, Ueno T, Yamamoto A, Kirisako T, Noda T et al. LC3, a mammalian homologue of yeast Apg8p, is localized in autophagosome membranes after processing. EMBO J 2000; 19: 5720-5728.

27. Lum JJ. Growth factor regulation of autophagy and cell survival in the absence of apoptosis. Cell 2005; 120: 237-248.

28. Samejima K, Tone S, Earnshaw WC. CAD/DFF40 nuclease is dispensable for high molecular weight DNA cleavage and stage I chromatin condensation in apoptosis. J Biol Chem 2001; 276: 45427-45432.

29. Deveraux QL, Roy N, Stennicke HR, Van Arsdale T, Zhou Q, Srinivasula SM et al. IAPs block apoptotic events induced by caspase- 8 and cytochrome $c$ by direct inhibition of distinct caspases. EMBO J 1998; 17: 2215-2223.

30. Chua BT, Guo K, Li P. Direct cleavage by the calcium-activated protease calpain can lead to inactivation of caspases. J Biol Chem 2000; 275: 5131-5135.

31. Barbouti A, Amorgianiotis C, Kolettas E, Kanavaros P, Galaris D. Hydrogen peroxide inhibits caspase-dependent apoptosis by inactivating procaspase-9 in an iron-dependent manner. Free Radical Bio Med 2007; 43: 1377-1387.

32. Kuroda J, Kimura S, Strasser A, Andreeff M, O'Reilly LA, Ashihara E et al. Apoptosis-based dual molecular targeting by INNO-406, a second-generation Bcr-Abl inhibitor, and ABT737, an inhibitor of antiapoptotic Bcl-2 proteins, against Bcr-Abl-positive leukemia. Cell Death Differ 2007; 14: 1667-1677.

33. Strasser A, O'Connor L, Dixit VM. Apoptosis signaling. Annu Rev Biochem 2000; 69: 217-245

34. Marsden VS, O'Connor L, O'Reilly LA, Silke J, Metcalf D, Ekert PG et al. Apoptosis initiated by Bcl-2-regulated caspase activation independently of the cytochrome c/Apaf-1/caspase9 apoptosome. Nature 2002; 419: 634-637.

35. Liu JR, Opipari AW, Tan L, Jiang Y, Zhang Y, Tang $\mathrm{H}$ et al. Dysfunctional apoptosome activation in ovarian cancer: implications for chemoresistance. Cancer Res 2002; 62 : 924-931.

36. Johnstone RW, Ruefli AA, Lowe SW. Apoptosis: a link between cancer genetics and chemotherapy. Cell 2002; 108: 153-164.

37. Bratton SB, Walker G, Srinivasula SM, Sun XM, Butterworth M, Alnemri ES et al. Recruitment, activation and retention of caspases- 9 and -3 by Apaf-1 apoptosome and associated XIAP complexes. EMBO J 2001; 20: 998-1009.

38. Carter BZ, Kornblau SM, Tsao T, Wang RY, Schober WD, Milella M et al. Caspaseindependent cell death in AML: caspase inhibition in vitro with pan-caspase inhibitors or in vivo by XIAP or Survivin does not affect cell survival or prognosis. Blood 2003; 102 4179-4186.

39. McQueen T, Kornblau SM, Konopleva M, Edwards K, Andreeff M, Cortes J et al. Caspaseindependent cell death in AML: an in vivo study in patients undergoing chemotherapy [abstract]. Blood 2001; 98: 208b.

40. Ito $T$, Tanaka H, Kimura A. Establishment and characterization of a novel imatinib-sensitive chronic myeloid leukemia cell line MYL, and an imatinib-resistant subline MYL-R showing overexpression of Lyn. Eur J Haematol 2007; 78: 417-431. 